\title{
The Impact of Supervision Characteristics of Board of Commissioners on Tax Aggressiveness
}

\author{
Anastasia Niniek \\ Politeknik Keuangan Negara-STAN \\ Tangerang Selatan, Indonesia \\ anastasia.niniek@pajak.go.id
}

\author{
Riko Riandoko \\ Politeknik Keuangan Negara-STAN \\ Tangerang Selatan, Indonesia \\ riandoko@stan.ac.id
}

\author{
Muhammad Rheza Ramadhan \\ Politeknik Keuangan Negara-STAN \\ Tangerang Selatan, Indonesia \\ muhammad.rhezaramadhan@pajak.go.id
}

\begin{abstract}
This study aims to find the effect of supervision characteristics of the board of commissioners on tax aggressiveness. Supervision characteristics of the board of commissioners are proxied by four proxies: risk management system and internal control, big- 4 audit firm, external auditor independence, and independence of the internal audit committee. Tax aggressiveness is proxied with GAAP ETR. Based on regression result with random effect model, it was found that the supervision characteristics of the board of commissioners did not affect tax aggressiveness.
\end{abstract}

Keywords-supervision characteristics, board of commissioner, tax aggressiveness, tax avoidance

\section{INTRODUCTION}

Tax ratio is one tool that shows the ability of the government in collecting tax revenue (Secretariat General of the House of Representatives, 2011, 1). As mandated in Law No. 17 of 2003 on State Finance, tax revenue is one of the pillars of state revenue in the Indonesian State Budget (APBN). Figure 1 shows Indonesia's tax ratio over the last five years.

Fig. 1. Indonesia's tax ratio over the last five years

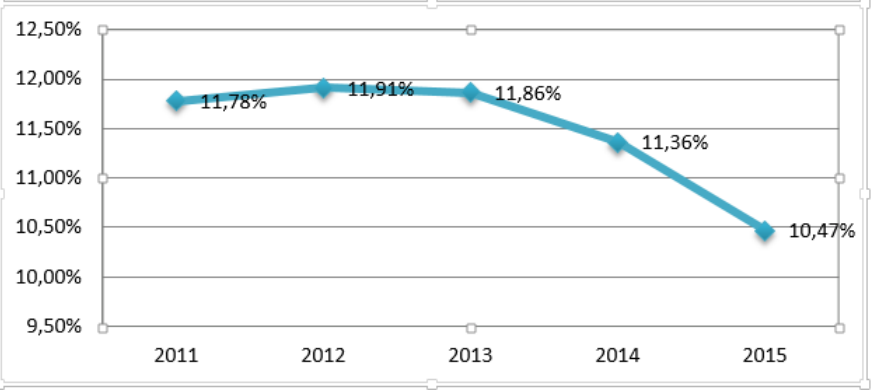

The tax ratio in Figure 1 is still considered low compared to the tax ratio of other countries. For example, Misbakhun who is a member of Commission XI of the House of Representatives stated that Indonesia is still categorized as lower middle income country with low tax ratio because the average value of tax ratio in lower middle income countries in 2015 is $17.7 \%$ (http: //www.republika.co.id/berita/ekonomi/makro/16/11/21/ogzwd n336-dpr-request-the-government-only-reading-reformasipajak, January 16, 2017). Another example is shown in Figure 2. Misbakhun said that the low tax value of Indonesia shows the low awareness of taxpayers in paying taxes.
Fig. 2. ASEAN countries' tax ratio

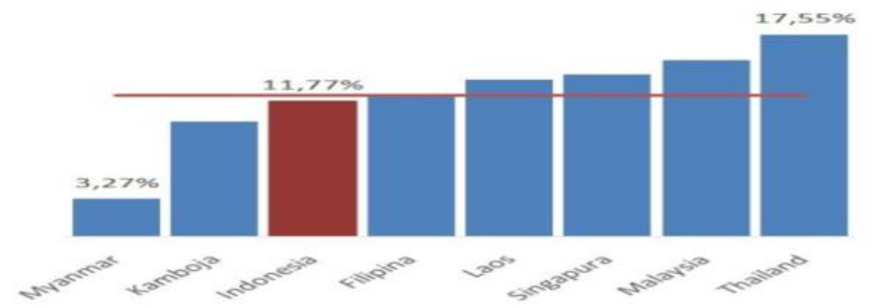

Midiastuty et al. (2016) states that a lack of awareness of taxation is still experienced by taxpayers in Indonesia, especially corporate taxpayers. taxpayers Agency considers taxes as a burden that reduces income and does not provide direct rewards. This causes the taxpayers Agency to seek ways to reduce the tax burden or become aggressive in its taxation (Chen et al., 2010 in Midiastuty et al., 2016). Frank et al. (2009) defines aggressive acts in taxation as an act aimed at revamping corporate taxable profits through tax planning, both legally and illegally. There are several proxies that can be used to measure tax aggressiveness, such as effective tax rate (ETR), book-tax differences (BTD), and unrecognized tax benefits (UTB) (Hanlon and Heitzman, 2010).

Desai and Dharmapala (2006) in his research stated that the decision on tax aggressiveness done by the company made by management. This decision is made because management has the opportunity to benefit from the control they have over the company. Conversely, shareholders may not want management to engage in tax aggressiveness as it can provide greater opportunities for management to benefit themselves and tax aggressiveness does not always provide greater value to shareholders (Desai and Dharmapala, 2006).

Shareholders may reduce the probability of corporate tax aggressiveness by management through the implementation of good corporate governance as stated by the Australian Taxation Office (ATO, 2006, 2010) in Richardson, Taylor, and Lanis (2013). In its tax compliance program, ATO stresses that the strength of corporate governance structures has a major impact on the likelihood of corporate tax aggressiveness. In Indonesia, the Directorate General of Taxes has not issued specific rules on governance of the WP Agency, but the Financial Services Authority (OJK) in the Indonesian Corporate Governance Roadmap states that the Indonesian government has generally paid special attention to the 
implementation of good corporate governance as stated in Law Number 40 Year 2007 regarding Limited Liability Company. As a capital market legislator, OJK has also issued OJK Regulation Number 21 / POJK.04 / 2015 on Implementation of Open Corporate Governance Guidelines and Circular Letter (SE) OJK Number 32 / SEOJK.04 / 2015 on Open Corporate Governance Guidelines.

One of the organs in corporate governance is the board of commissioners. Law Number 40 Year 2007 states that the duty of the board of commissioners is to supervise and give advice to the directors. In agency theory, shareholders as principals have limited access issues in overseeing management behavior as agents so management can act opportunistically (Bouckova, 2015), so the task of this oversight is delegated to the board of commissioners.

Several studies have shown that supervisory characteristics by the board of commissioners have a role in reducing the likelihood of tax aggressiveness in companies. One is the Lanis and Richardson (2011) research which shows that the proportion of larger independent members of the board of commissioners is able to reduce the likelihood of tax aggressiveness. In Indonesia, the study of Midiastuty et al. (2016) also showed similar results to the research of Lanis and Richardson (2016). Another example is Richardson, Taylor, and Lanis (2013) research that examines the application of risk management and internal control systems, the use of big-4 audit firms, the independence of external auditors, and the independence of the internal audit committees of open companies in Australia. The results of this study indicate that the four characteristics of supervision is able to reduce the possibility of aggressive action in taxation on the company. In Indonesia, Phinandito (2016) conducted a similar study by analyzing the effect of the implementation of the risk management system and internal controls, the use of big-4 audit firm services, and the independence of the internal audit committee on tax aggressiveness. The results of this study show only the use of services big-4 audit firm that has a significant influence on corporate tax aggressiveness.

Still lack of research in Indonesia similar to Richardson, Taylor, and Lanis (2013) research makes the writer interested to raise research with this theme. In addition, there are several large open companies that have implemented some of the four characteristics of supervision, but still have problems in taxation, namely PT Astra Otoparts Tbk and PT Matahari Putra Prima Tbk. According to the Income Tax Act, the general rate of income tax on corporate taxpayers, which also applies to both companies, is $25 \%$. However, the calculation of ETR, which is the result of the division of the Company's income tax to the company's pretax income, represents a $10.09 \%$ yield in 2012, $16.60 \%$ in 2013, and $13.69 \%$ in 2014 for PT Astra Otoparts Tbk and $10.79 \%$ in 2012, 23.95\% in 2013, 24.19\% in 2014 and $18.26 \%$ in 2015 for PT Matahari Putra Prima Tbk. The author wants to know whether the value of ETR indicating an aggressive action in taxation by both companies is influenced by the application of supervisory characteristics by the board of commissioners.
During the year 2012 s.d. 2014, PT Astra Otoparts Tbk stated that it has implemented internal risk management and internal control system effectively in its annual report. PT Astra Otoparts Tbk also uses the services of a big-4 audit firm to audit its financial statements and all members of its audit committee are independent members. While PT Matahari Putra Prima Tbk, during the period of 2012 s.d. 2015, states that it has implemented an internal risk management and internal control system effectively in its annual report and states that all members of the audit committee of the company are independent members.

The lack of research in Indonesia similar to Richardson's, Taylor's and Lanis's research (2013) and the still aggressive discovery of taxation by companies that impose some supervisory characteristics by their board of commissioners attracted the authors to research the theme. Therefore, the authors raise the title of this study as follows: "Influence Characteristics Supervision Board of Commissioners Aggressive to Corporate Taxes".

\section{THEORY AND HYPOTHESIS DEVELOPMENT}

\section{A. Tax Aggressiveness}

Frank et al. (2009) defines tax aggressiveness as an act aimed at revamping corporate taxable profits through tax planning, both legally and illegally. The definition is in line with the definition of tax aggressiveness described by Richardson, Taylor, and Lanis (2013), which is management action to decrease taxable income through tax planning activities in both legal areas, "gray" areas and illegal areas. But according to Hanlon and Heitzman (2010), there is no general definition of tax aggressiveness as there is no generally accepted definition of tax avoidance.

Hanlon and Heitzman (2010) stated that there is no clear boundary between tax avoidance and tax aggressiveness. There is a difference in subjectivity between individuals in defining how aggressive a behavior is to be referred to as tax evasion. However, many studies use various terms, such as tax aggressiveness, tax sheltering, tax evasion, and so on, to define tax planning activities approaching illegal areas (Hanlon and Heitzman, 2010). Similarly, in this study, the tax aggressiveness measures referred to in this study are those approaching illegal areas.

According to Hanlon and Heitzman (2010), there are several ways or proxies that can be used to measure tax aggressiveness, including GAAP effective tax rate (ETR), long-run ETR, book-tax differences (BTD), abnormal BTD, and unrecognized tax (UTB). The proxy used in this study is GAAP ETR, obtained through the distribution of income tax expense on income before tax.

\section{B. Board of Commissioner Supervision Characterictics}

\section{Risk Management System and Internal Control}

Reding et al. (2013, 4-4) defines enterprise risk management as a process by management to understand and overcome the uncertainty that can affect the organization's ability to achieve its objectives. Meanwhile, the Committee of Sponsoring Organizations of the Treadway Commission 
(COSO) in Reding et al. (2013, 4-4) defines enterprise risk management as follows:

A process, effected by an entity's board of directors, management, and other personnel, applied in strategy setting and across the enterprise, designed to identify potential events that may affect the entity, and manage risk to be within its risk appetite, assurance regarding the achievement of entity objectives.

COSO in Reding et al. (2013, 6-4) defines internal control as "a process, effected by an entity's board of directors, management, and other personnel, designed to provide reasonable assurance about the achievement of objectives relating to operations, reporting and compliance." Canadian Insitute of Chartered Accountants (CICA) in Reding et al. (2013, 6-4) defines internal control as follows:

The effectiveness and efficiency of operations, the reliability of internal and external reporting, the compliance with laws and regulations, and internal policies.

From the various definitions above, it can be concluded that both the risk management system and internal controls implemented by the company to provide adequate assurance on the achievement of corporate objectives. To that end, the Financial Report Council or FRC (2014) states that both must be run simultaneously as an indivisible unity. From the agency theory perspective, the risk management and internal control systems are part of the mechanisms established by management as agents to ensure that they will behave in the interests of shareholders as principals (Godfrey et al., 2006, 302).

The internal control system has become the company's main corporate governance mechanism for managing risk (Rae et al., 2008 in Richardson, Taylor, and Lanis, 2013). The Board of Commissioners has a role as the holder of a key oversight mechanism to mitigate any residual losses incurred for shareholders and control agency problems (Fama and Jensen, 1983). The board of commissioners receives authority over internal control and other decisions of shareholders so that the board of commissioners has a position as the apex of decision control in the company (Fama and Jensen, 1983; Richardson, Taylor, and Lanis, 2013).

Rae et al. (2008) states that the company's internal controls serve as an important corporate governance tool. They add that the responsibility for implementing an effective risk management integration framework lies with managers. The design of internal controls and compliance with established policies and procedures is an important aspect of the framework. Effective risk management and internal control systems can support the board of commissioners in monitoring and managing risks. The results of several studies (eg DeAngelo et al., 1994; Beasley, 1996; Yermack, 1996; Klein, 1998; Uzun et al., 2004; Karamanou and Vafeas, 2005 in Richardson, Taylor, and Lanis, 2013) Effective oversight of management has fewer possibilities to engage in fraudulent financial and corporate reporting.

The rules applicable to the recognition and control of business risks generally apply to tax risks (Erle, 2008 in Richardson, Taylor, and Lanis, 2013) so that taxes can be said to be an important component of risk management and internal control systems (Richardson, Taylor, and Lanis, 2013). Board of commissioners has an obligation to participate in tax risk management. The tax risk in question includes the risk of paying taxes less than that required in the tax laws and reputation damages arising from such errors may result in additional costs for the company (Erle, 2008 in Richardson, Taylor, and Lanis, 2013).

\section{Big-4 Audit Firm}

Big-4 audit firms are the designation for a group of four largest accounting firms in the world. These firms provide a variety of accounting and auditing services, including external audits, tax services, management and business consulting, and risk assessment and control. The four companies include Deloitte Touche Tohmatsu Limited, PricewaterhouseCoopers (PwC), Ernst \& Young (E \& Y), and Klynveld Peat Marwick Goerdeler (KPMG).

Richardson, Taylor, and Lanis (2013) stated that the use of big-4 audit firm services can help companies reduce their tax aggressiveness through increased supervision and audit quality. According to Dewi and Jati (2014), audit quality is any possibility that may occur when auditors audit auditee financial statements and find that there are violations that occur and report it in audited financial statements. There are four benchmarks in assessing audit quality, namely professionalism, accountability, integrity, and transparency (Tehupuring, 2016). In relation to corporate taxes, firms tend to tax aggressiveness to avoid high tax reporting. Therefore, to ensure the quality of information related to taxation, the auditor is required to audit the financial statements of the company to ensure the reliability of information (Tehupuring 2016).

Rezaee (2005) in Richardson, Taylor, and Lanis $(2013,72)$ argues that big-4 audit firms are more likely to detect financial reporting fraud than non-big-4 audit firms because they have greater ability to resist pressure of clients, paying more attention to reputation and big names, more resources (in the areas of engineering and technology expertise), and more advanced and systematic audit strategies and processes. However, the big-4 audit firm also has the possibility to develop and market various tax aggressive schemes that allow their clients to report high profits on the one hand and pay lower corporate taxes on the other (Sikka 2010 in Richardson, Taylor, and Lanis, 2013). For example, the case of Enron in which the tax aggressiveness scheme was designed by Arthur Andersen and Deloitte and Touche.

\section{Independence of External Auditor}

According to Sikka and Hampton (2005) and Freise et al. (2008) in Richardson, Taylor, and Lanis (2013, 72), the provision of non-audit services by an external auditor to its auditee company may affect the independence of the external 
auditor so that there is a debate regarding the precision of such non-audit services. Becker et al. (1998) in Richardson, Taylor, and Lanis (2013) mentions that the large costs paid by companies to external auditors for non-audit services increase the financial dependence of external auditors on the company. In Indonesia, the Capital Market and Financial Institution Supervisory Agency (Bapepam LK) has issued Decision Number 86 / BL / 2011 on the Independence of Accountants Providing Services in the Capital Market. In Rule Number VIII.A.2 number 3 letter d, it is mentioned that the accountant, Public Accounting Firm (KAP), and Insider of Public Accountant Firm (Persons in KAP) are deemed not independent if during the audit period, accountant, KAP, and insider KAP provides non attestation services to clients, such as:

a. bookkeeping or other services related to the client's accounting records or financial statements;

b. design of financial information systems and implementation;

c. internal audit;

d. management consulting;

e. human resource consultation;

f. financial advisor;

g. tax services, unless it has obtained prior approval from the Audit Committee; or

h. other services that may create a conflict of interest.

i. With regard to taxation services, the Audit Committee's approval does not include tax services to represent clients inside or outside tax court and / or acting for and on behalf of clients in tax calculations and reporting.

\section{Independence of Internal Audit Commitee}

Fama and Jensen (1983) in Richardson, Taylor, and Lanis (2013, 74) state that an independent audit committee is considered to enhance the company's reputation through more effective oversight of management. Abbott er al. (2000) in Richardson, Taylor, and Lanis $(2013,74)$ argues that there is evidence to support the idea that an independent audit committee can prevent aggressive financial reporting and accounting fraud. The audit committee is expected to be able to assess the nature of the accounting policies used as well as the accounting and taxation estimates made by the management company. The audit committee is also required to be able to measure the reasons for the use of methodologies and assumptions in preparing accounting and tax information, why audit adjustments are made, the role of management in the audit process, as well as the evaluation and evaluation of the integrity of the company's annual financial statements (Klein 2002 in Richardson, Taylor, and Lanis, 2013).

\section{Prior Research}

Research that explicitly examines the relationship between important board supervisory characteristics, in addition to the composition of the board of commissioners, and corporate tax aggressiveness is still rare (Richardson, Taylor, and Lanis, 2013). Here are some studies that have been done before:
1. Desai and Dharmapala (2006)

Mihir A. Desai and Dharmapala Dhammika (2006), in his research entitled Corporate Tax Avoidance and High-Powered Incentives, used tax sheltering as the dependent variable and manager incentive compensation as the independent variable. The results obtained from this study are high-powered incentives in companies that do not have good governance have a significant negative effect on tax sheltering, but no effect on companies that have good governance.

2. Lanis and Richardson (2011)

Roman Lanis and Grant Richardson (2011), in his research entitled The Effect of the Board of Directors of Composition on Corporate, use tax aggressiveness as the dependent variable and the composition of the board of commissioners as independent variables. The results obtained from this study is the increase in the proportion of independent members on the board of commissioners reduce the level of corporate tax aggressiveness.

3. Richardson, Taylor, and Lanis (2013)

Grant Richardson, Grantley Taylor and Roman Lanis (2013), in his research entitled The Impact of Board of Directors of Oversight Characteristics on Corporate Tax Aggressiveness: An Empirical Analysis, using tax aggressiveness as its dependent variable, as well as internal risk management and control systems, the external auditor, the independence of the external auditor, and the independence of the audit committee as an independent variable. The results obtained from this study are the four independent variables have a significant influence in reducing the aggressiveness of corporate taxes.

4. Armstrong et al. (2015)

Christopher S. Armstrong, Jennifer L. Blouin, Alan D. Jagolinzer, and David F. Larcker (2015), in his research entitled Corporate Governance, Incentives, and Tax Avoidance, use tax avoidance as the dependent variable, as well as management incentives and board characteristics commissioners as independent variables. The result of this research is risk-taking equity incentives have positive effect to tax avoidance and independence of board of commissioner have negative effect to tax avoidance.

5. Pinandhito (2016)

Alvin Kautsar Pinandhito (2016), in his research entitled The Effect of Internal Control, Auditor Quality, Audit Committee Independence, Company Size, and Leverage Against Tax Aggressiveness, using tax aggressiveness as its dependent variable, as well as internal control and risk management systems, auditor quality, audit committee, firm size, and leverage as independent variables. The results obtained from this study is only the quality of auditors that significantly influence the aggressiveness of corporate taxes, while other independent variables are not.

\section{Hypothesis}

The hypothesis formulated in this study is derived from the results of research conducted by Richardson, Taylor, and Lanis (2013) which shows the result that supervision by the board of commissioners has a significant effect to reduce the aggressiveness of corporate taxes. Based on theoretical basis 
and the results of the prior research, the authors formulate the following hypothesis:

H1: Assuming other factors remain, the company where its board of commissioners establishes an effective risk management and internal control system negatively affects corporate tax aggressiveness.

$\mathrm{H} 2$ : Assuming other factors remain, the use of big-4 audit firm services negatively affects the tax aggressiveness of the company.

H3: Assuming other factors remain, the independence of a weak external auditor positively affects corporate tax aggressiveness.

H4: Assuming other factors remain, the independence of the internal audit committee negatively affects the tax aggressiveness of the company.

\section{RESEARCH METHOD}

\section{A. Scope}

The scope of this research is the companies that have been included in the Compass 100 Index list for the period of 2012 s.d. 2015 and objects in this study is data from financial statements and annual reports of these companies that represent each variable in this study.

Number of companies that have been included in the Compass 100 Index list for the period of 2012 s.d. 2015 is 154 companies. The author considers the number to be able to represent 537 companies listed on the IDX as of September 2016. Richardson, Taylor and Lanis (2013) research used the top 300 Australian publicly-listed firms of 2,164 companies listed on the Australian Securities Exchange. As of April 2016, the top 300 firms represented $73 \%$ of the stock market capitalization in Australia (https://www.asx300list.com/, accessed on January 03, 2017). As stated in BEI Stock Price Index Handbook (2010), the stock selection process included in the computation of the Compass 100 Index also considers the market capitalization factor of those shares.

Data is selected using some of the following considerations:

1. Companies listed in the Compass 100 Index for the year 2012 s.d. 2015.

2. Companies that publish annual financial statements and annual reports consistently from 2012 s.d. 2015. The selection of this year's range is based on the year after the issuance of the Governance Risk Management Implementation Guidelines by the National Committee on Governance Policy (KNKG) in 2011.

3. Companies other than in sectors that are regulated separately by the authorities, covering the financial services sector and the sub-sector of investment companies.

4. Companies other than those whose income is subject to Final Income Tax, such as a construction company. Final Income Tax has a tariff that is different from corporate income tax in general.

5. Companies other than those who do not pay the Income Tax / receive income tax benefit and / or suffer an accounting loss between the range of 2012 s.d. 2015.

\section{B. Variables}

1. Dependent Variable

The dependent variable in this study is represented by the corporate tax aggressiveness (TAG). The researchers collected the TAG measure directly from the company's financial statements using the proxy effective tax rates (ETR). The ETR used in this study is GAAP ETR. GAAP ETR is used because in Richardson, Taylor, and Lanis (2013) research, hypothesis testing using this proxy gives the closest results to the results of hypothesis testing using the main proxy. The main proxy is measured using a dummy variable of the company's involvement in a tax dispute with ATO in terms of tax aggressiveness under Australian tax laws.

\section{Independent Variable}

The independent variables in this study include:

a. Risk management system and internal control (RMS)

It is a statement of the company's management on the effectiveness of the risk management system and the internal controls prevailing in its company. RMS is expected to have a negative sign.

b. External auditor type (AUD)

It is the use of the services of big- 4 audit firms or not by the company in auditing its annual financial statements. AUD is expected to have a negative sign.

c. Independence of external auditors (EAI)

It is the financial dependence of the external auditor on the client company (auditee) due to the non-audit services provided. EAI is expected to have a positive sign.

d. Independence of internal audit committee (ACI)

Is the proportion of independent members in the firm's audit committee. ACI is expected to have a negative sign.

\section{Control Variables}

The control variables in this study include:

a. Company size (SIZE)

SIZE was used in this study to control the effect of size. Prior research (Tran, 1997 in Richardson, Taylor, and Lanis, 2013; Richardson and Lanis, 2007) found that larger firms were more likely to be tax-aggressive because they had superior economic and political power over small firms (Siegfried, 1972 in Richardson, Taylor , and Lanis, 2013) and are able to reduce the tax burden accordingly.

b. Leverage (LEV)

Previous research (Stickney and McGee, 1982 in Richardson, Taylor, and Lanis, 2013; Gupta and Newberry, 1997 in Richardson, Taylor, and Lanis, 2013) found that LEV has a positive relationship with tax aggressiveness as interest payments may reduce taxes.

c. Capital Intensity (CINT)

Previous research (Stickney and McGee, 1982 in Richardson, Taylor and Lanis, 2013; Gupta and Newberry, 1997 in Richardson, Taylor, and Lanis, 2013) found that CINT has a positive relationship with tax aggressiveness as a result of accelerated depreciation expenses based on asset life .

d. R \& D Intensity (RDINT)

Previous research (Stickney and McGee, 1982 in Richardson, Taylor, and Lanis, 2013; Gupta and Newberry, 1997 in Richardson, Taylor, and Lanis, 2013) found that RDINT has a positive relationship of tax aggressiveness because R \& D burdens can reduce taxes. 
e. Inventory intensity (INVINT)

INVINT is a substitute for CAPINT, so intensive inventory companies should be less aggressive in taxes than intensive firms in capital (Stickney and McGee, 1982 in Richardson, Taylor, and Lanis, 2013).

f. The existence of subsidiaries in tax haven countries according to OECD (FTH)

FTH controls the corporate utilization of tax-haven countries. The utilization is positively associated with tax aggressiveness as it is done to minimize the overall corporate tax position (Desai et al., 2006; Taylor and Richardson, 2012). g. Market to book ratio (MKTBK)

MKTBK is a growth control variable. Previous studies (Gupta and Newberry, 1997 in Richardson, Taylor, and Lanis, 2013; Adhikari et al., 2006 in Richardson, Taylor, and Lanis, 2013) provide conflicting results.

h. Return on assets (ROA)

ROA is a profitability control variable. Previous studies (Gupta and Newberry, 1997 in Richardson, Taylor, and Lanis, 2013; Adhikari et al., 2006 in Richardson, Taylor, and Lanis, 2013) provide conflicting results.

i. Securities industry sector (INDSEC)

INDSEC is a dummy variable, which is included as a control variable in this study because there is a possibility of tax aggressiveness fluctuating in different industrial sectors (Omer et al., 1993 in Richardson, Taylor, and Lanis, 2013). There are nine industrial sectors organized under the Jakarta Industrial Classification (JASICA), which include: the agricultural sector; mining sector; basic industrial and chemical sectors; various industry sectors; the consumer goods industry sector; property sector, real estate, and building construction; infrastructure, utilities and transport sectors; the financial sector; as well as trade, services and investment sectors. However, only eight sectors were used in this study, ie all sectors outside the financial sector.

j. Effect year (YEAR)

YEAR is a dummy variable and is included as a control variable in this study to control the differences in aggressive corporate tax activity that may exist during the 2012 sample s.d. 2015.

\section{Model}

In this study, the authors used the model used Richardson, Taylor, and Lanis (2013) in his research as follows:

$T A G_{i t}=\alpha_{0}+\beta_{1} R M S_{i t}+\beta_{2} A U D_{i t}+\beta_{3} E A I_{i t}+\beta_{4} A C I_{i t}+\beta_{5} S I Z Z_{i t}+\beta_{6} L E V_{i t}+\beta_{7} C I N T_{i t}+\beta_{8} R D I N T_{i t}$ $+\beta_{9} I N V I N T_{i t}+\beta_{10} F T H_{i t}+\beta_{11} M_{K T B K}+\beta_{12} R_{i t} O A_{i t}+\beta_{13-18} I N D S E C_{i t}+\beta_{19-21} Y{ }^{2} R_{i}$

$$
+\varepsilon_{\text {it }}
$$

\section{Data Analysis and Hypothesis Testing}

This study uses panel data. The first step taken on the data that has been collected is to perform a descriptive statistical analysis.

After presenting the data using descriptive statistics conducted, it will be tested using three models of panel data testing. The three results of this test is one of the basic to choose the best model that can be used to test hypothesis in research. Chow Test, Lagrange Multiplier Test, and Hausman Test will be conducted to select the best model in research data. The model to be selected is between common effects models, fixed effects, and random effects.
After obtaining the best model to get the regression equation according to the research data, it will be tested classical assumption. Classic assumption tests include autocorrelation test, normality test, multicollinearity test, and heteroscedasticity test. Autocorrelation test can be done by conducting Durbin-Watson test. Multicollinearity test can be done by using linear regression to see the correlation between independent variables used in the study. Heteroskedasticity test can be done by conducting Glejser test and analysis of plots data result in diagram form. While the data normality test can be done by Kolmogorov-Smirnov test and analysis of the normal result of probability plots. The classical assumption test will be selected based on the result of regression model selection.

Multiple linear regression testing is done by model approach which has been chosen to take the conclusion whether the model can explain the effect of independent variable to dependent variable simultaneously (Fifth Significance Test). Hypothesis testing is done by t-test. The $t$ test statistic value of the independent variables can be used to assess the effect of independent variables individually on the dependent variable of the study.

\section{RESULT AND DISCUSSION}

\section{A. Sampling}

Table 1 shows the results of the sample selection that has been implemented. The result of purposive sampling in this research are 51 companies and preliminary observation data used in this research is 204 company-years.

TABLE 1 Purposive Sampling

\begin{tabular}{|l|l|l|}
\hline 1 & $\begin{array}{l}\text { Companies in the Compass 100 Index list for } \\
\text { the period of August 2014 - January 2015 }\end{array}$ & 154 Companies \\
\hline 2 & $\begin{array}{l}\text { Companies that do not publish annual } \\
\text { financial statements and annual reports } \\
\text { consistently from 2012-. 2015 }\end{array}$ & 12 Companies \\
\hline 3 & $\begin{array}{l}\text { Companies included in sectors that are } \\
\text { regulated separately by the Company's }\end{array}$ & 22 companies \\
\hline 4 & $\begin{array}{l}\text { Companies whose income is subject to Final } \\
\text { Income Tax }\end{array}$ & 27 Companies \\
\hline 5 & $\begin{array}{l}\text { Companies that do not pay Income Tax / } \\
\text { receive Income Tax benefits and or } \\
\text { experience an accounting loss between the } \\
\text { range of 2012 s.d. 2015 }\end{array}$ & 42 Companies \\
\hline & $\begin{array}{l}\text { Total Samples } \\
\text { Year }\end{array}$ & 204 companies-years \\
\hline & Total years & 51 companies \\
\hline
\end{tabular}

\section{B. Descriptive Statistics}

The author performs a descriptive statistical analysis of the research data as shown in Appendix 1, using the Eviews program 9. Some outputs of the analysis are as follows: mean; median; maximum; minimum; and sum.

\section{Hypothesis Testing}

After the model selection as described in the previous section, it is found that the appropriate model is a random 
effect model. Then, after doing BLUE test and random effect regression analysis hence got result as showed in appendix 2 .

\section{Determination Coefficient}

Appendix 2 shows the value of R2 overalls in this study is 0.2440 . This means that the contribution of all variables in the model to the variation of dependent variable is $24.40 \%$, while the rest, which is $75.60 \%$, is explained by other factors not included in the regression model in this study.

\section{F-test}

Appendix 2 shows prob score $>$ chi2 in this study is 0.0004 . The prob value> chi2 is smaller than alpha $(5 \%)$ so $\mathrm{H} 0$ is rejected or all variables in the model simultaneously have a significant effect on the dependent variable.

\section{3. t-test}

Based on Table 3 taken from appendix 2, H0 is accepted for all independent variables in this study. RMS, AUD, and ACI variables have $\mathrm{P}>|\mathrm{z}|$ value above alpha $(0,05)$, whereas EAI variable has regression coefficient marks that do not match with prediction marks.

TABLE 2 t-test

\begin{tabular}{|c|c|c|c|c|}
\hline \multirow{2}{*}{ Variable } & Code & Prediction Sign & $\mathbf{P}>|\mathbf{z}|$ & Sign \\
\hline Dependent & TAG & & \multicolumn{2}{|c|}{} \\
\hline \multirow{5}{*}{ Independent } & RMS & - & 0,1865 & - \\
\cline { 2 - 5 } & AUD & - & 0,4890 & - \\
\cline { 2 - 5 } & EAI & + & 0,0005 & - \\
\cline { 2 - 5 } & ACI & - & 0,4030 & + \\
\hline
\end{tabular}

\section{Hypothesis 1 testing}

The first hypothesis (H1) in this study is assuming other factors remain, the company where its board of commissioners determines the system of risk management and effective internal control negatively affect the aggressiveness of corporate tax. To know the acceptance or rejection of this hypothesis, must be seen how the influence of risk management system variables and internal control (RMS) to variable aggressiveness of corporate taxation (TAG).

Table 2 shows that the $\mathrm{P}>|\mathrm{z}|$ value of the RMS variable is 0.1865 and the resulting coefficient sign is (-) or negative. The decision taken is that $\mathrm{H} 1$ is rejected or with other fixed factor assumptions, the company where its board of commissioners establishes an effective risk management system and internal control does not negatively affect the tax aggressiveness of the company. This result is contrary to the results of research by Richardson, Taylor, and Lanis (2013).

\section{Hypothesis 2 testing}

The second hypothesis (H2) in this study is assuming other factors remain, the use of services big- 4 audit firm negatively affect the aggressiveness of corporate taxes. To know the acceptance or rejection of this hypothesis, it must be seen how the influence of external auditor type variable (AUD) to the variable aggressiveness of corporate taxation (TAG).

Table 2 shows that the $\mathrm{P}>|\mathrm{z}|$ value of the AUD variable is 0.4890 and the resulting coefficient sign is (-). Decision taken is $\mathrm{H} 2$ rejected or with other factor assumptions remain, the use of services big-4 audit firm does not negatively affect the aggressiveness of corporate tax. This result is contrary to the results of research by Richardson, Taylor, and Lanis (2013).

\section{Hypothesis 3 testing}

The third hypothesis (H3) in this study is assuming other factors remain, the independence of a weak external auditor positively affect the aggressiveness of corporate taxes. To know the acceptance or rejection of this hypothesis, it must be seen how the influence of external auditor independence variable (EAI) to variable aggressiveness of corporate taxation (TAG).

Table 2 shows that the $\mathrm{P}>|\mathrm{z}|$ value of the EAI variable is 0,0005 and the resulting coefficient sign is (-) or negative so that the decision taken is $\mathrm{H} 3$ rejected or with other factor assumptions fixed, the independence of a weak external auditor has no effect positive against corporate tax aggressiveness. This result is contrary to the results of research by Richardson, Taylor, and Lanis (2013).

\section{Hypothesis 4 testing}

The fourth hypothesis (H4) in this study is assuming other factors remain, the independence of the internal audit committee negatively affect the aggressiveness of corporate taxes. To know the acceptance or rejection of this hypothesis, it must be seen how the influence of internal audit committee independence variable (ACI) to variable aggressiveness of company taxation (TAG).

Table 2 shows that the $\mathrm{P}>|\mathrm{z}|$ value of the ACI variable is 0.4030 and the resulting ACI coefficient is (+) or positive so that the decision taken is $\mathrm{H} 4$ rejected or with other factor assumptions fixed, the independence of the internal audit committee has no effect negative to corporate tax aggressiveness. This result is contrary to the results of research by Richardson, Taylor, and Lanis (2013).

\section{Discussion}

All hypotheses in this study are rejected so that it can be concluded that supervision by the board of commissioners is not able to reduce the practice of tax aggressiveness committed by the management company. The commissioner and supervisory function undertaken is part of corporate governance. In Indonesia, there are several studies that provide similar results with this study. For example, Hanum's (2013) research results in Ariyani (2014) show that the characteristics of corporate governance have no significant effect on ETR. The results of Angela's (2014) study also show that governance characteristics do not have a significant effect on corporate tax aggressiveness. 
The results of this study contradict the results of research Richardson, Taylor, and Lanis (2013) who use the object of research in Australia. This may be due to differences in governance practices in Australia and Indonesia. In Australia, listed companies are required to own and implement governance under the ASX Corporate Governance Principles and Recommendations. In Indonesia, listed companies have not been required to own and implement governance until 2016 after the issuance of OJK Regulation Number $21 /$ POJK.04 / 2015 and SE OJK Number 32 / SEOJK.04 / 2015. For the previous years, KNKG has issued the General Guidelines of Good Corporate Governance of Indonesia, but the guidelines are not yet an obligation to be performed listed company.

Explanation about the influence of each of the characteristics of supervisory board of commissioner against tax aggressiveness described as follows.

\section{a. The effect of RMS on TAG}

The first hypothesis is rejected or assuming other factors remain, the company in which its board of commissioners establishes an effective risk management system and internal control does not negatively affect the tax aggressiveness of the company. Furthermore, the results of this study indicate that the company in which its board of commissioners establishes an effective risk management system and effective internal control has no effect on corporate tax aggressiveness. This result is contrary to the results of Richardson, Taylor, and Lanis (2013) research. However, the results of this study are consistent with the results of research Pinandhito (2016). This may be due to differences in Australian and Indonesian rules regarding risk management and internal control.

In Australia, ASX Principle 7 Guidelines require the company's chief executive officer (CEO) and chief financial officer (CFO) to provide information to the board of commissioners regarding the effectiveness of the implementation of the risk management system and internal controls. If the CEO and CFO can not assert that the company's internal risk management and control systems are operating effectively, then they should state explicitly in the company's annual report. In Indonesia, KNKG issued the 1999 Indonesian General Good Corporate Governance Guidelines, which were subsequently revised in 2001 and 2006. The guidelines state that the directors need to provide statements regarding the effectiveness of the implementation of internal controls, which also includes risk management, in its annual report. However, such guidelines are not yet an obligation that an open company must carry out until the issuance of OJK Regulation No. 21 / POJK.04 / 2015 and SE OJK Number 32 / SEOJK.04 / 2015 valid from 2016.

\section{b. Effect of AUD on TAG}

The second hypothesis is rejected or with other factor assumptions fixed, the use of big-4 audit firm services does not negatively affect the aggressiveness of corporate taxes. Furthermore, the results of this study indicate that the use of the services of big-4 audit firms has no effect on corporate tax aggressiveness. This result contradicts the results of Richardson, Taylor, and Lanis (2013) and Francis (2004) research. However, the results of this study are consistent with the results of Tehupuring (2016), Sari et al. (2016), and Wibawa et al. (2016).

There are several reasons why this hypothesis may be rejected. First, audits by big-4 firm audits and non-big-4 firm audits do not have a significant difference in mitigating tax evasion practices (Tehupuring 2016). Second, Sari et al. (2016) that basically, big-4 audit firms tend to be more trusted because they always apply the existing rules in quality. However, if the company can provide better benefits and welfare, a reputable KAP can commit fraud to maximize its welfare. Third, the quality of external auditors has no significant effect on tax evasion because all KAPs in Indonesia have basically audited in accordance with the prevailing regulations (Wibawa et al., 2016).

c. The effect of EAI on TAG

The third hypothesis is rejected or with other factor assumptions fixed, the independence of a weak external auditor does not positively affect the aggressiveness of corporate taxes. This result is contrary to the results of Richardson, Taylor, and Lanis (2013) and Frankel et al. (2002). However, the results of this study are consistent with the results of Kinney et al. (2004), Krishnan and Visvanathan (2011), as well as Lennox (2016).

The proxy used in this study is the proportion of fees for non-audit services paid to the external auditor of the total cost paid to the external auditor. There are some similar conditions for external auditors both in Indonesia and in the United States (US) in order to be declared independent. One is not to provide non audit services to the auditee for the same period with the period of audit services. One of the non-audit services in Rule Number VIII.A.2 point $3 \mathrm{~d}$ in Bapepam LK Decree Number 86 / BL / 2011 concerning Independence of Accountant Providing Services in Capital Market is taxation service. Krishnan and Visvanathan (2011) and Lennox (2016) use objects in the US where taxation services are also nonaudit services so companies often obtain audit services of financial statements and taxation services from two different parties.

The reason given by Lennox (2016) for the results of his research is that with the difference of parties providing audit services and tax services, the exchange of information between financial information and taxation information becomes more difficult to do so the quality of audits performed becomes lower. Another reason is that the party providing taxation services has no responsibility for the financial health of the company so they can provide tax advice that may lead to material misstatements in the company's financial statements.

d. The effect of ACI on TAG

The fourth hypothesis is rejected or with other factor assumptions fixed, the independence of the internal audit committee does not negatively affect the aggressiveness of the corporate tax. Furthermore, the results of this study indicate that the independence of internal audit committees has no influence on the aggressiveness of corporate taxes. This result is contrary to the results of Richardson, Taylor, and Lanis 
(2013) and Abbott et al. (2000). However, the results of this study are consistent with the results of several previous studies.

In Indonesia, Ariyani's (2014) and Pinandhito (2016) studies show that audit committee independence has no significant effect on tax aggressiveness. The results of both studies may be related to the implementation of Rule Number IX.I.5 number 2 and item 3 letter $b$ in the Decision of the Chairman of Bapepam LK Number 29 / PM / 2004 on the Formation and Implementation Guidelines of the Audit Committee. The rule forces the company to have an independent audit committee. Research outside of Indonesia that has similar results with this research is Klein (2002) research in the US and Dridi and Boubaker (2016) in Tunisia. As in Indonesia, every member of the audit committee of a company in the US must also be declared independently under the Sarbanes-Oxley Act.

\section{CONCLUSION AND SUGGESTION}

\section{A. Conclusion}

Based on test results and discussion in Chapter IV, the authors conclude several things as follows:

The result of $t$ test for the RMS variable shows the value of 0.1865 and the resulting coefficient sign is (-) so that the first hypothesis in this study is rejected or with other fixed factor assumptions, the company in which its board of commissioners determines the system of risk management and effective internal control has no effect negative to corporate tax aggressiveness.

The $t$ test result for the AUD variable shows the value of 0.4890 and the resulting coefficient sign is (-) so that the second hypothesis in this study is rejected or with other factor assumptions fixed, the use of big-4 audit firm services does not negatively affect the tax aggressiveness of the firm.

The result of $t$ test for EAI variable shows the value of 0.0005 and the resulting coefficient sign is (-) or negative so that the third hypothesis in this study is rejected or with other factor assumption fixed, the independence of weak external auditor does not positively influence to corporate tax aggressiveness.

The result of $t$ test for ACI variable shows the value of 0.4030 and the resulting coefficient sign is $(+)$ so that the fourth hypothesis in this study is rejected or with other factor assumptions fixed, the independence of the internal audit committee does not negatively affect the tax aggressiveness of the company.

Control variables that significantly affect the aggressiveness of corporate taxes are SIZE, YEAR2, and YEAR3. SIZE has a positive effect on corporate tax aggressiveness, while YEAR2 and YEAR3 have a negative effect on corporate tax aggressiveness.

The regression model has fulfilled the goodness of fit. Based on the coefficient of determination (R2) concluded that the contribution of all independent variables and control on variation of dependent variable is $24.40 \%$, while the rest of $75.60 \%$ is explained by other factors not included in the regression model in this study.
Based on the result of F statistic test, all independent and control variables simultaneously have a significant effect on the aggressiveness of corporate tax at $95 \%$ level.

\section{B. Limitation}

This research has several limitations in its implementation, which include:

1. Use of Kompas List 100 as one of the criteria of research sample. Richardson, Taylor, and Lanis (2013) research employed a top 300 Australian publicly-listed firms selected solely on the basis of stock market capitalization. However, in Indonesia, there is no index that selects the company only based on the stock market capitalization as in Australia.

2. Use of ETR GAAP is not a major proxy in calculating the dependent variable in Richardson, Taylor, and Lanis (2013) research. The main proxies in the study were measured using a dummy variable, ie when in the first year of the sample period 2006 s.d. 2009 companies are involved in tax disputes with ATOs related to tax aggressiveness under Australian tax laws, then the proxy will be assigned a value of one (1), otherwise zero (0). This measurement method can be used in Australia because Australian Accounting Standard AASB 137 on Provisions, Contigent Liabilitites, and Contigent Assets in Richardson, Taylor, and Lanis (2013) requires companies to disclose information regarding the company's involvement in the tax dispute. However, this method of calculation can not be used in Indonesia because PSAK does not regulate similar matter so that the collection of data related to this main proxy is difficult to do.

3. Different rules relating to statements by key personnel for the effectiveness of risk management and internal control implementation in Australia and Indonesia so that the method of calculating RMS variables in Australia is more adequate than in Indonesia. In Australia, CEOs and CFOs are required to provide such statements whereas in Indonesia, directors are only advised to make such statements.

4. Calculation of EAI variables using non audit costs and total costs paid to external auditors. In Indonesia, data related to both costs are not always disclosed by the company in its financial statements because there is no mandatory rule. In contrast, in Australia, the company is required to disclose audit fees or reviews related to the financial statements and other service fees paid to the external auditor for a separate period as provided in AASB 1054 on Australian Additional Disclosures (2011).

5. The use of normal probability plot charts that can be misleading if not used carefully for normality tests.

6. Differences in corporate governance practices in Australia and Indonesia. In Australia, listed companies have been required to own and implement governance while in Indonesia it has not been required until 2016. For the previous years, KNKG has issued the General Guidelines for Good Corporate Governance of Indonesia, but the guidelines are not yet an obligation to be implemented. The Corporate Governance Principles and Recommendations issued by ASX set eight principles of governance that must be adhered to by listed companies. For each principle, ASX outlines some recommendations in detail. Meanwhile, the general guidelines published by KNKG only regulate five principles and three corporate governance organs. The five principles include transparency, accountability, responsibility, 
independence, and equality and fairness, while the three organs in question include general meeting of shareholders (AGM), board of commissioners, and board of directors. The governance principles and recommendations for companies in Indonesia are further stipulated in SE OJK Number 32 / SEOJK.04 / 2015 valid from 2016. In the circular letter, OJK outlines the eight principles of corporate governance and its recommendations.

\section{Suggestion}

From the results of this study there are several suggestions that the author can provide as follows:

1. Using other criteria for sampling in subsequent research, eg companies that enter the manufacturing sector or all companies listed on the Stock Exchange.

2. Using proxies other than GAAP ETR to measure TAG variables in subsequent research. Other proxies may include cash ETR, BTD, BTD residual, and other tax aggressive proxies.

3. Using other, more definite proxies to measure RMS variables in subsequent research, eg the existence of the Risk Management Committee.

4. Using other proxies whose data are more adequate to measure EAI variables in subsequent studies, such as the length of the firm's relationship with its external auditor.

5. Using statistical tests for normality tests in subsequent research so that the normality of research data is more assured.

6. The Directorate General of Tax shall not focus on the effectiveness of internal control and risk management, the type of external auditor, the independence of the external auditor, and the independence of the audit committee in performing its duties as tax authorities in Indonesia.

\section{REFERENCES}

[1] G. Eason, B. Abbott, L. J., Y. Park, and S. Parker. 2000. The effects of audit committee activity and independence on corporate fraud. Citated by Grant Richardson, Grantley Taylor, and Roman Lanis. 2013. The impact of board of director oversight characteristics on corporate tax aggressiveness: An empirical analysis. Journal of Accounting and Public Policy 32: 68-88.

[2] Adhikari, Ajay Adhikari, Chek Derashid, and Hao Zhang. 2006. Public policy, political connections, and effective tax rates: Longitudinal evidence from Malaysia. Citated by Grant Richardson, Grantley Taylor, and Roman Lanis. 2013. The impact of board of director oversight characteristics on corporate tax aggressiveness: An empirical analysis. Journal of Accounting and Public Policy 32: 68-88.

[3] Akbar, M. 2016. DPR minta Pemerintah segera laksanakan reformasi pajak. Republika, $21 \quad$ November 2016 http://www.republika.co.id/berita/ekonomi/makro/16/11/21/ogzwdn336dpr-minta-pemerintah-segera-laksanakan-reformasi-pajak (diakses pada 16 Januari 2017).

[4] Armstrong Christopher S., Jennifer L. Blouin, Alan D. Jagolinzer, and David F. Larcker. 2015. Corporate governance, incentives, and tax avoidance. Journal of Accounting and Economics 60: 1-17.

[5] Australian Taxation Office. 2006. Large business and tax compliance. Citated by Grant Richardson, Grantley Taylor, and Roman Lanis. 2013. The impact of board of director oversight characteristics on corporate tax aggressiveness: An empirical analysis. Journal of Accounting and Public Policy 32: 68-88.

[6] 2010. Large business and tax compliance. Citated by Grant Richardson, Grantley Taylor, and Roman Lanis. 2013. The impact of board of director oversight characteristics on corporate tax aggressiveness: An empirical analysis. Journal of Accounting and Public Policy 32: 68-88.

[7] Baltagi, Badi H. 2005. Econometric Analysis of Panel Data. Edisi ke-3. Chichester: John Wiley \& Sons Ltd.

[8] Beasley, M. S.. 1996. An empirical analysis of the relation between the board of director composition and financial statement fraud. Citated by Grant Richardson, Grantley Taylor, and Roman Lanis. 2013. The impact of board of director oversight characteristics on corporate tax aggressiveness: An empirical analysis. Journal of Accounting and Public Policy 32: 68-88.

[9] Becker, C., M. Defond, J. Jiambalvo, and K. R. Subramanyam. 1998. The effect of audit quality on earnings management. Citated by Grant Richardson, Grantley Taylor, and Roman Lanis. 2013. The impact of board of director oversight characteristics on corporate tax aggressiveness: An empirical analysis. Journal of Accounting and Public Policy 32: 68-88.

[10] Bouckova, Marketa. 2015. Management Accounting and Agency Theory. Procedia Economics and Finance 25: 5-13.

[11] Bursa Efek Indonesia. 2014. Peng-00529/BEI.OPP/07-2014 tentang Pengumuman Saham yang Masuk and Keluar dalam Penghitungan Indeks KOMPAS100 http://www.idx.co.id/Portals/0/StaticData/MarketInformation/ListOfSec urities/IndexConstituent/KOMPAS100/20140722-Peng00529_BEI.OPP_Ags14-Jan15.pdf (diakses tanggal 22 September 2016).

[12] Chen, S., X. Chen, Q Cheng, and T. Shevlin. 2010. Are family firms more tax aggressive than non family firms. Citated by Midiastuty, Pratana Puspa, Eddy Suranta, Rini Indriani, and Sarry Irawaty Putri. 2016. Pengaruh kepemilikan pengendali and corporate governance terhadap tindakan pajak agresif. Prosiding Simposium Nasional Akuntansi XIX Lampung 2016.

[13] DeAngelo, H., L. DeAngelo, and D. J. Skinner. 1994. Accounting choice in troubled companies. Citated by Grant Richardson, Grantley Taylor, and Roman Lanis. 2013. The impact of board of director oversight characteristics on corporate tax aggressiveness: An empirical analysis. Journal of Accounting and Public Policy 32: 68-88.

[14] Desai, Mihir A. and Dhammika Dharmapala. 2006. Corporate tax avoidance and high-powered incentives. Journal of Financial Economics 79: $145-179$.

[15] Dewi, Ni Nyoman Kristiana and I Ketut Jati. 2014. Pengaruh karakter eksekutif, karakteristik perusahaan, and dimensi tata kelola perusahaan yang baik pada tax avoidance di Bursa Efek Indonesia. E-Jurnal Akuntansi Universitas Udayana 6.2: 249-260.

[16] Direktorat Jenderal Anggaran. 2016. Informasi APBN Perubahan 2016 Republik Indonesia. http://www.kemenkeu.go.id/APBNP2016 (diakses tanggal 21 September 2016).

[17] _ 2016. Refleksi Tingkat Kepatuhan Wajib Pajak. http://www.pajak.go.id/content/article/refleksi-tingkat-kepatuhan-wajibpajak (diakses tanggal 22 September 2016).

[18] Edhy, Djaka Saranta S. 2003. Dasar-dasar Perpajakan di Indonesia. Tangerang: Sekolah Tinggi Akuntansi Negara.

[19] Erle, B. 2008. Tax risk management and board responsibility. Citated by Grant Richardson, Grantley Taylor, and Roman Lanis. 2013. The impact of board of director oversight characteristics on corporate tax aggressiveness: An empirical analysis. Journal of Accounting and Public Policy 32: 68-88.

[20] Fama, Eugene F. and Michael C. Jensen. 1983. Agency problem and residual claims. Journal of Law Economics 26 (2): 327-249.

[21] Field, Andy. 2013. Discovering Statistics Using IBM SPSS Statistics. Edisi ke-4. London: SAGE Publications Ltd.

[22] Financial Reporting Council. 2014. Guidance on Risk Management, Internal Control, and Related Financial and Business Reporting. London: Financial Reporting Council Limited.

[23] Francis, J. R.. 2004. What do we know about audit quality? Citated by Grant Richardson, Grantley Taylor, and Roman Lanis. 2013. The impact of board of director oversight characteristics on corporate tax aggressiveness: An empirical analysis. Journal of Accounting and Public Policy 32: 68-88. 
[24] Frank, M., L. Lynch, and S. Rego. 2009. Tax reporting aggressiveness and its relation to aggressive financial reporting. The Accounting Review 82: 467-496.

[25] Frankel, R., M. Johnson, and K. Nelson. 2002. The relation between auditors' fees for non-audit services and earning management. The Accounting Review 77: 71-105.

[26] Freise, A., S. Link, and S. Mayer. 2008. Taxation and Corporate Governance-The State of The Art. Citated by Grant Richardson, Grantley Taylor, and Roman Lanis. 2013. The impact of board of director oversight characteristics on corporate tax aggressiveness: An empirical analysis. Journal of Accounting and Public Policy 32: 68-88.

[27] Ghozali, Imam. 2013. Aplikasi Analisis Multivariate dengan Program IBM SPSS 23. Semarang: Baand Penerbit Universitas Diponegoro.

[28] Godfrey, Jayne, Allan Hodgson, Scott Holmes, and Ann Tarca. 2006. Accounting theory. Edisi ke-6. Milton: John Wiley and Sons Australia, Ltd.

[29] Gujarati, Damodar N. 2003. Basic econometrics. Edisi ke-4. New York: McGraw-Hill.

[30] Gupta, Sanjay and Kaye Newberry. 1997. Determinants of the variability on corporate effective tax rates: Evidence from longitudinal data. Citated by Grant Richardson, Grantley Taylor, and Roman Lanis. 2013. The impact of board of director oversight characteristics on corporate tax aggressiveness: An empirical analysis. Journal of Accounting and Public Policy 32: 68-88.

[31] Hanlon, Michelle and Shane Heitzman. 2010. A review of tax research. Journal of Accounting and Economics 50: 127-178.

[32] Harris, Mark N. and Simon Feeny. 1999. The determinants of corporate tax rates: evidence from Australia. Melbourne Institute Working Paper, no. 21 .

[33] Ikatan Akuntan Indonesia. PSAK 57 tentang Provisi and Kontijensi

[34] Indonesia Stock Exchange. 2010. Buku Panduan Indeks Harga Saham Bursa Efek Indonesia. Jakarta: Indonesia Stock Exchange.

[35] Isroah. 2013. Perpajakan. Yogyakarta: Universitas Negeri Yogyakarta. http://staff.uny.ac.id/sites/default/files/pendidikan/Isroah,\%20Dra.\%20M .Si./BUKU\%20PERPAJAKAN.pdf (diakses tanggal 4 Desember 2016).

[36] Jensen, M.. 2000. Theory of firm: governance, residual claims, and organizational forms. Citated by Marketa Bouckova. 2015. Management Accounting and Agency Theory. Procedia Economics and Finance 25: $5-13$.

[37] Karamanou, I. and N. Vafeas. 2005. The association between corporate boards, audit committees, and management earnings forecasts: An empirical analysis. Citated by Grant Richardson, Grantley Taylor, and Roman Lanis. 2013. The impact of board of director oversight characteristics on corporate tax aggressiveness: An empirical analysis. Journal of Accounting and Public Policy 32: 68-88.

[38] Klein, April. 1998. Firm performance and board committee structure. Citated by Grant Richardson, Grantley Taylor, and Roman Lanis. 2013. The impact of board of director oversight characteristics on corporate tax aggressiveness: An empirical analysis. Journal of Accounting and Public Policy 32: 68-88.

[39] 2002. Audit committee, board of director characteristics, and earning management. Journal of Accounting and Economics 33: 375-400.

[40] Koran Sindo. 2016. Dirjen Pajak Sandera Petinggi PT SIP. http://economy.okezone.com/read/2016/04/21/320/1368724/dirjenpajak-sandera-petinggi-pt-sip (diakses tanggal 30 November 2016).

[41] Lambert, Richard A.. 2001. Contracting Theory and Accounting. Citated by Marketa Bouckova. 2015. Management Accounting and Agency Theory. Procedia Economics and Finance 25: 5-13.

[42] Lanis, Romas and Grant Richardson. 2011. The effect of board of director composition on corporate tax aggressiveness. Journal of Accounting Public Policy 30: 50-70.

[43] Manzon Jr., Gil B. and George A. Plesko. 2002. The relation between financial and tax reporting measures of income. Citated by Mihir A. Desai and Dhammika Dharmapala. 2006. Corporate tax avoidance and high-powered incentives. Journal of Financial Economics 79: 145-179.

[44] Midiastuty, Pratana Puspa, Eddy Suranta, Rini Indriani, and Sarry Irawaty Putri. 2016. Pengaruh kepemilikan pengendali and corporate governance terhadap tindakan pajak agresif. Prosiding Simposium Nasional Akuntansi XIX Lampung 2016.

[45] Nachrowi, Nachrowi D. and Hardius Usman. 2006. Pendekatan Populer and Praktis Ekonometrika untuk Analisis Ekonomi and Keuangan. Jakarta: Lembaga Penerbitan FEUI.

[46] Pinandhito, Alvin Kautsar. 2016. Pengaruh Pengendalian Internal, Kualitas Auditor, Independensi Komite Audit, Ukuran Perusahaan, and Leverage terhadap Agresivitas Pajak (Studi Empiris Perusahaan Manufaktur yang Terdaftar di BEI Periode 2011-2014). Universitas Diponegoro: Semarang.

[47] Rae, K., N. Subramaniam, and J. Sands. 2008. Risk management and ethical environment: Effects on internal audit and accounting control procedures. Journal of Applied Management Accounting Research 6: 11-30.

[48] Reding, Kurt F., Paul J. Sobel, Urton L. Anderson, Michael J. Head, Sridhar Ramamoorti, Mark Salamasick, and Cris Riddle. 2013. Internal Auditing. Altamonte Springs: The Institute of Internal Auditors Research Foudation (IIARF).

[49] Rezaee, Z.. 2005. Causes, consequences, and deterrence of financial statement fraud. Citated by Grant Richardson, Grantley Taylor, and Roman Lanis. 2013. The impact of board of director oversight characteristics on corporate tax aggressiveness: An empirical analysis. Journal of Accounting and Public Policy 32: 68-88.

[50] Richardson, Grant and Roman Lanis. 2007. Determinants of the variability in corporate effectiveness tax rates and tax reform: Evidence from Australia journal. Journal of Accounting and Public Policy 26: 689-704.

[51] Richardson, Grant, Grantley Taylor, and Roman Lanis. 2013. The impact of board of director oversight characteristics on corporate tax aggressiveness: An empirical analysis. Journal of Accounting and Public Policy 32: 68-88.

[52] Santoso, Singgih. 2016. Panduan Lengkap SPSS Versi 23. Jakarta: PT Elex Media Komputindo.

[53] Sari, Nila, Nawang Kalbuana, and Agus Jumadi. 2016. Pengaruh konservatisme akuntansi, kualitas audit, ukuran perusahaan terhadap penghindaran pajak. Syariah Paper Accounting FEB UMS: 431-440.

[54] Siegfried, John. 1972. The relationship between economic structure and the effect of political influence: Empirical evidence from the federal corporation income tax program. Citated by Grant Richardson, Grantley Taylor, and Roman Lanis. 2013. The impact of board of director oversight characteristics on corporate tax aggressiveness: An empirical analysis. Journal of Accounting and Public Policy 32: 68-88.

[55] Sikka, P. and M. P. Hampton. 2005. The role of accountancy firms in tax avoidance: Some evidence and issues. Citated by Grant Richardson, Grantley Taylor, and Roman Lanis. 2013. The impact of board of director oversight characteristics on corporate tax aggressiveness: An empirical analysis. Journal of Accounting and Public Policy 32: 68-88.

[56] Sikka, P. 2010. Smoke and mirrors: corporate social responsibility and tax avoidance. Citated by Grant Richardson, Grantley Taylor, and Roman Lanis. 2013. The impact of board of director oversight characteristics on corporate tax aggressiveness: An empirical analysis. Journal of Accounting and Public Policy 32: 68-88.

[57] Stickney, Clyde P. and Victor E. McGee. 1982. Effective corporate tax rates: The effect of size, capital intensity, leverage, and other factors. Citated by Grant Richardson, Grantley Taylor, and Roman Lanis. 2013. The impact of board of director oversight characteristics on corporate tax aggressiveness: An empirical analysis. Journal of Accounting and Public Policy 32: 68-88.

[58] Sugiyono. 2010. Metode Penelitian Bisnis. Bandung: Alfabeta.

[59] 2011. Metode Penelitian Kuantitatif, Kualitatif, and R\&D. Bandung: Alfabeta, 90.

[60] Suwardi, Akbar. 2011. Stata: Tahapan and Perintah (Syntax) Data Panel. Depok: Universitas Indonesia.

[61] Taylor, Grantley and Grant Richardson. 2012. International corporate tax avoidance practices: Evidence from Australian firms. The International Journal of Accounting 47, 469-496.

[62] Tehupuring, Ronald. 2016. Pengaruh koneksi politik and kualitas audit terhadap praktik penghindaran pajak di lembaga perbankan yang 
terdaftar di pasar modal Indonesia periode 2012-2014. Prosiding Seminar Nasional INDOCOMPAC: 366-376.

[63] Tran, Alfred. 1997. The gap between accounting profit and taxable income. Citated by Grant Richardson, Grantley Taylor, and Roman Lanis. 2013. The impact of board of director oversight characteristics on corporate tax aggressiveness: An empirical analysis. Journal of Accounting and Public Policy 32: 68-88

[64] Uzun, H., S. H. Szewczyk, and R. Varma. 2004. Board composition and corporate fraud. Citated by Grant Richardson, Grantley Taylor, and Roman Lanis. 2013. The impact of board of director oversight characteristics on corporate tax aggressiveness: An empirical analysis. Journal of Accounting and Public Policy 32: 68-88.

[65] Widarjono, Agus. 2007. Ekonometrika: Teori and Aplikasi Untuk Ekonomi and Bisnis. Edisi ke-2. Yogyakarta: Ekonisia FE Universitas Islam Indonesia.

[66] William, D. F.. 2007. Developing the Concept of Tax Governance. Citated by Grant Richardson, Grantley Taylor, and Roman Lanis. 2013. The impact of board of director oversight characteristics on corporate tax aggressiveness: An empirical analysis. Journal of Accounting and Public Policy 32: 68-88.

[67] Winarno, Wing Wahyu. 2015. Analisis Ekonometrika and Statistika dengan Eviews. Edisi ke-4. Yogyakarta: UPP STIM YKPN.

[68] Winosa, Yosi. 2016. Realisasi penerimaan pajak sepanjang 2015 capai 81,5 persen. Berita Satu, 2 Januari 2016. http://www.beritasatu.com/ekonomi/337472-realisasi-penerimaan-pajaksepanjang-2015-capai-815-persen.html (diakses pada 29 Oktober 2016).

[69] www.idx.co.id/idid/beranda/perusahaantercatat/laporankeuangandantahunan.aspx

[70] Yermack, D.. 1996. Higher market valuation of companies with a small board of directors. Citated by Grant Richardson, Grantley Taylor, and Roman Lanis. 2013. The impact of board of director oversight characteristics on corporate tax aggressiveness: An empirical analysis. Journal of Accounting and Public Policy 32: 68-88.

[71] Zuber, Jill M. 2007. Corporate manager aggressiveness in tax decision making. Fayetteville: Dissertation of Philosophy University of Arkansas.

[72] Indonesia. Undang-Undang Nomor 6 Tahun 1983 tentang Ketentuan Umum and Tata Cara Perpajakan sebagaimana telah beberapa kali diubah terakhir dengan Undang-Undang Nomor 16 Tahun 2009. http://www.kemenkeu.go.id/sites/default/files/UU-KUP\%20Mobile.pdf (diakses tanggal 2 Desember 2016).

[73] Indonesia. Undang-Undang Nomor 40 Tahun 2007 tentang Perseroan Terbatas.

[74] Indonesia. Undang-Undang Nomor 12 Tahun 2016 tentang Perubahan atas Undang-Undang Nomor 14 Tahun 2015 tentang Anggaran Pendapatan and Belanja Negara Tahun Anggaran 2016. http://www.kemenkeu.go.id/Data/uu-apbn-p-tahun-2016 (diakses tanggal 21 September 2016).

[75] Indonesia. Laporan Keuangan Pemerintah Pusat Tahun 2015 (Audited)

[76] Baand Pengawas Pasar Modal and Lembaga Keuangan. Keputusan Ketua Bapepam LK Nomor 29/PM/2004 tentang Pembentukan and Pedoman Pelaksanaan Kerja Komite Audit

[77] . Keputusan Ketua Bapepam LK Nomor 86/BL/2011 tentang Independensi Akuntan yang Memberikan Jasa di Pasar Modal Otoritas Jasa Keuangan

[78] Otoritas Jasa Keuangan. Peraturan OJK Nomor 21/POJK.04/2015 tentang Penerapan Pedoman Tata Kelola Perusahaan Terbuka

[79] . Peraturan OJK Nomor 55/POJK.04/2015 tentang Pembentukan and Pedoman Pelaksanaan Kerja Komite Audit

[80] . Surat Edaran OJK Nomor 32/SEOJK.04/2015 tentang Pedoman Tata Kelola Perusahaan Terbuka

[81] . Roadmap Tata Kelola Perusahaan Indonesia 
APPENDIX 1 Descriptive Statistics

\begin{tabular}{|c|c|c|c|c|c|c|c|c|c|c|c|c|c|}
\hline & TAG & RMS & AUD & EAl & $\mathrm{ACl}$ & SIZE & CINT & INVINT & LEV & RDINT & FTH & MKTBK & ROA \\
\hline Mean & $-0,276420$ & 0,897059 & 0,715686 & 0,001218 & 0,970588 & 29,56194 & 0,323974 & 0,158297 & 0,171485 & 0,001073 & 0,176471 & 2,563760 & 0,135292 \\
\hline Median & $-0,251476$ & 1,000000 & 1,000000 & 0,000000 & 1,000000 & 29,81315 & 0,287535 & 0,111671 & 0,150752 & 0,000000 & 0,000000 & 2,255000 & 0,105588 \\
\hline Maximum & $-0,078345$ & 1,000000 & 1,000000 & 0,203014 & 1,000000 & 33,13405 & 0,975357 & 0,642019 & 0,918535 & 0,019882 & 1,000000 & 58,48000 & 0,577180 \\
\hline Minimum & $-0,947617$ & 0,000000 & 0,000000 & 0,000000 & 0,000000 & 22,59466 & 0,000000 & 0,000000 & 0,009902 & 0,000000 & 0,000000 & $-241,6800$ & 0,003630 \\
\hline Std. Dev. & 0,125560 & 0,304630 & 0,452197 & 0,014286 & 0,102077 & 1,765827 & 0,191254 & 0,137810 & 0,141363 & 0,003409 & 0,382158 & 18,98224 & 0,116275 \\
\hline Skewness & $-2,891762$ & $-2,613243$ & $-0,956296$ & 13,92324 & $-5,348269$ & $-1,138466$ & 0,926192 & 1,048404 & 1,404064 & 3,845009 & 1,697337 & $-10,231030$ & 1,799070 \\
\hline Kurtosis & 14,01227 & 7,829040 & 1,914502 & 197,0603 & 43,19730 & 5,885520 & 3,589361 & 3,688406 & 6,338566 & 17,57415 & 3,880952 & 136,6876 & 6,394739 \\
\hline Jarque-Bera & 1315,113 & 430,4042 & 41,10866 & 326695,9 & 14707,03 & 114,8405 & 32,11874 & 41,39934 & 161,7687 & 2308,109 & 104,5490 & 155474,1 & 208,0023 \\
\hline Probability & 0,000000 & 0,000000 & 0,000000 & 0,000000 & 0,000000 & 0,000000 & 0,000000 & 0,000000 & 0,000000 & 0,000000 & 0,000000 & 0,000000 & 0,000000 \\
\hline Sum & $-56,389740$ & 183,0000 & 146,0000 & 0,248534 & 198,0000 & 6030,636 & 66,09066 & 32,29268 & 34,98288 & 0,218940 & 36,00000 & 523,0071 & 27,59956 \\
\hline Sum Sq. Dev. & 3,200382 & 18,83824 & 41,50980 & 0,041433 & 2,115196 & 632,9832 & 7,425365 & 3,855293 & 4,056643 & 0,002358 & 29,64706 & 73146,05 & 2,744523 \\
\hline Observations & 204 & 204 & 204 & 204 & 204 & 204 & 204 & 204 & 204 & 204 & 204 & 204 & 204 \\
\hline
\end{tabular}




\section{Atantis PRESS}

Advances in Economics, Business and Management Research (AEBMR), volume 46 APPENDIX 2 Random Effect Model

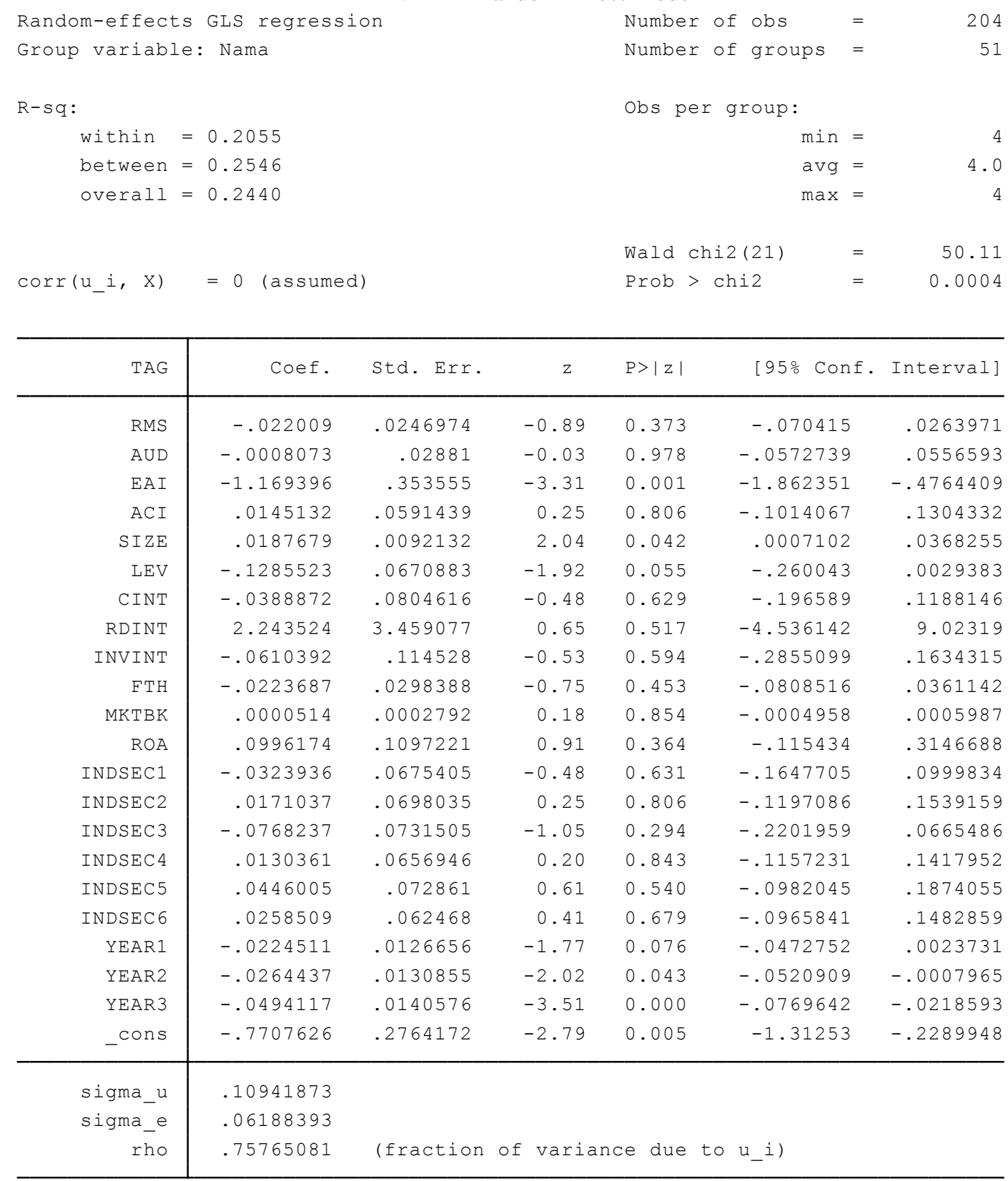

